Kong. Res. J. 3(1) : 32-36, 2016

ISSN 2349-2694

Kongunadu Arts and Science College, Coimbatore.

\title{
ETHNO-MEDICO-BOTANICAL STUDIES ON AQUATIC PLANTS IN RURAL AREAS OF CUDDALORE DISTRICT, TAMILNADU, INDIA
}

\author{
Saravanakumar, $\mathbf{K}$. \\ Botany Wing-DDE, Annamalai University, Annamalainagar - 608002. \\ E.mail: drsaravanak2007@gmail.com
}

\begin{abstract}
The present work was undertaken to explore the ethno-medico-botanical values of aquatic plants from rural areas of Cuddalore District in Tamilnadu, India. Traditional knowledge of 22aquatic plants was identified as medicinally important species from local residents, vaidya, other medicine men and from other sources. Collected information's are arranged in an alphabetical order followed by the sequence of scientific name, family, vernacular name, prescription and usage. Documentation of traditional knowledge of ethnomedico-botanical values of aquatic plant species will provide baseline information for investigating new biodynamic compounds of potential therapeutic uses in future.
\end{abstract}

Keywords: Documentation, Medicinal properties, aquatic plants, Cuddalore district.

\section{INTRODUCTION}

The knowledge of medicinal property of plants has been accumulated in the course of many centuries (Kirthikar and Basu, 1980). The local inhabitants have inherited rich traditional knowledge on the use of many plants or plant parts for treatment of common diseases (Vedavathy, 2003; Jain, 2004; Maity, et al., 2004). The remedies based on these plants often have minimal side effects (Lambert et al., 1997). Recently there is a paradigm shift from over use synthetic drugs to herbal medicines. The medicinal value of a particular species of plant differs from one locality to another or from one community to another. Hence, it is highly imperative to document local knowledge on the medicinal properties of plants to gain wider and in-depth knowledge on their curative abilities. It play a significant role in the primary production, nutrient cycling, and serve as bioindicators for eutrophication processes (Thangam et al., 2010; Regini Balasingh, 2011)

Hydrophytes grow profusely in lakes and waterways all over the world and have in recent decades their negative effects magnifies by man's intensive use of natural water bodies. Eradication of this water plants are has proved almost impossible and even reasonable control is difficult. The potential of aquatic plants as food and feed has been emphasized by several authors (Indirani, 2010; Lawrence, 2010). Large growths of hydrophytes in lakes and waterways of tropical countries, although a menace, represent a natural resource of green leaves (Lawrence, 2010). With increasing interest in finding new drugs, the wild or unutilized plants receive more attention which offers a good scope to meet the increasing demand for novel drug discovery.

Local people use a wide variety of wetland / wetland -associated plants as ingredients of traditional herbal medicinal preparations. Often the information on the composition of a specific medicinal preparation or the knowledge on the use and medical value of particular plant is restricted to a few members of a community or even to one or two individuals of a household. Since most of this vital system of knowledge is transmitted orally, the local extinction of a plant results in the gradual loss of knowledge related with the medicinal value of such species.

Documentation of ethno-botanical importance of terrestrial plant species was more than aquatic plant species. Maya et al. (2003) analyzed the economic importance of river vegetation of Kerala and gave the uses of 35 species including the bank specie apart from the aquatic/wetland species. Panda and Misra (2011) provided information about ethno medicinal uses of 48 wetland plant species of South Orissa and discussed their conservation. Swapna et al. (2011) made a review on the medicinal and edible aspects of 70 aquatic and wetland plants of India. Though the aquatic situations of India are rich repositories of various plant species, not much work has been under taken to explore the medicinal uses of them. 
Hence, the present study was carried out to document the ethnomedico-botanical values of aquatic plants in Cuddalore District of Tamilnadu, India

\section{MATERIALS AND METHODS}

The present study, the data collection and survey have been made by field visits during June 2012- April 2013 and focused mainly on the aquatic plant species used by different local vaidhyas and medicinemen in Cuddalore District $\left(11.75^{\circ} \mathrm{N} 79.75^{\circ} \mathrm{E}\right)$ of Tamilnadu, India for primary healthcare needs as reported by the informants/traditional healers. The large number of local people, medicine men, herbal informants and women chieftains were personally interviewed and requested to answer a few questions about the (i) local aquatic plants and their availability in the area; (ii) application of these plants in healthcare and the data were recorded time to time. The collected information of ethno-medicobotanical values of aquatic plants was arranged according to their alphabetical sequence such as scientific name, families, voucher specimen number, family, vernacular names, parts used, the therapeutic uses and method of usage of herbal preparations.

Table 1. Particulars regarding the name of the species, morphology of useful part, diseases, method of preparation and their mode of administration

\begin{tabular}{|c|c|c|c|c|}
\hline Sl.No & Botanical Name and Family & $\begin{array}{c}\text { Morphology of } \\
\text { useful part }\end{array}$ & Disease cured & $\begin{array}{c}\text { Method of preparation and mode of } \\
\text { administration }\end{array}$ \\
\hline 1. & $\begin{array}{l}\text { Alternanthera philoxeroides (Mart.) Griseb. } \\
\text { (Amaranthaceae) }\end{array}$ & Shoot & Dysentery & $\begin{array}{l}\text { The decoction of the young shoot is taken in } \\
\text { empty stomach twice a day. }\end{array}$ \\
\hline \multirow[t]{2}{*}{2.} & \multirow{2}{*}{$\begin{array}{l}\text { Alternanthera sessilis } \quad \text { (L.) } \quad \text { R.Br. ex } \text { DC. } \\
\text { (Amaranthaceae) }\end{array}$} & Leaves, twigs & Fever & $\begin{array}{l}\text { Decoction is taken with }(30-50 \mathrm{ml}) \text { two } \\
\text { principal meals. }\end{array}$ \\
\hline & & Root & Cataract & $\begin{array}{l}\text { Root of the fresh plant touched in the eyes five } \\
\text { times a day. }\end{array}$ \\
\hline \multirow[t]{2}{*}{3.} & \multirow[t]{2}{*}{ Ammania baccifera L. (Lythraceae) } & Leaves & $\begin{array}{l}\text { Oedema } \\
\text { Skin abcess }\end{array}$ & $\begin{array}{l}\text { Leaves are ground in water and the paste } \\
\text { applied on the area and repeated for } 3 \text { days. }\end{array}$ \\
\hline & & Whole plant & Gonorrhoea & $\begin{array}{l}\text { Two teaspoonful decoction of the entire plant } \\
\text { is taken orally twice a day for three week. }\end{array}$ \\
\hline \multirow{2}{*}{4.} & \multirow{2}{*}{$\begin{array}{l}\text { Bacopa monnerii (L.) Pennell } \\
\text { (Scrophulariaceae) }\end{array}$} & Leaves & Dysentery & The paste of the leaves are taken with rice. \\
\hline & & & Gastritis & $\begin{array}{l}\text { Leaf juice is taken orally to treat gastritis and } \\
\text { as liver stimulant. }\end{array}$ \\
\hline \multirow{5}{*}{6.} & \multirow[b]{3}{*}{ Centella asiatica L. (Apiaceae) } & Whole plant & Malarial fever & $\begin{array}{l}\text { Plant juice together with black pepper give } \\
\text { twice a day for three days. }\end{array}$ \\
\hline & & & Scabies & Leaf paste is applied on the affected portion. \\
\hline & & Leaves & $\begin{array}{l}\text { Spermatorrhoea } \\
\text { Mouth sores }\end{array}$ & $\begin{array}{l}\text { Extract of fresh leaves (one teaspoon) is given. } \\
\text { Five to six leaves are chewed four times a day. }\end{array}$ \\
\hline & \multirow[t]{2}{*}{$\begin{array}{l}\text { Commelina bengalensis } \mathrm{L} . \\
\text { (Commelinaceae) }\end{array}$} & Leaves & Fever & $\begin{array}{l}\text { 5-10 leaves were fed into patient early } \\
\text { morning for } 2-3 \text { days. }\end{array}$ \\
\hline & & Whole plant & Herpes & Whole plant paste is applied externally. \\
\hline
\end{tabular}


7. Cyperus rotundus L. (Cyperaceae)

Eichhornia crassipes (Mart) Solms

8. (Pontederiaceae)

10.

pomoea aquatica Forster (Convolvulaceae)

\section{Hygrophila auriculata (Schumacher) Heine} (Acanthaceae)

Leaves

Whole plant

Leaves

Twigs

Leaves

Whole plant

Leaves

11. (Mart.exChoisy) Austin

(Convolvulaceae)

Leaves, Root

Whole plant

Ludwigia adscendens (L.) Hara

(Onagraceae)
Intestinal worms, Colic

complaints

Snake bite

Spermatorrhoea

Bone fracture

Anaemia

Body swellings

Leucorrhoea

Infantile diarrhea

Blood dysentery,

Indigestion

Piles

Itching

Snanke bite

Wounds and boils

Bone fracture

Stomach pain

Intestinal worms

Rheumatism
Crushed tubers are given with milk.

Tuber powder mixed with cow butter is given

to patients .

Two tubers per day are given with water for 5

days.

Plants are pounded and paste then applied .

The decoction of the young leaves are taken orally for two consecutive weeks in empty stomach.

Whole plant paste in applied over it.

Powdered leaf is given with water.

A handful of leaves pounded together with

black pepper and eaten twice daily.

Special type of curry is pre pared with young twigs and taken with rice.

Leaf paste is given topically.

Plant paste is applied over the body.

About 25g leaves are ground and taken with

$250 \mathrm{~g}$ curd for a week as an antidote for snake bite.

Leaves are warmed with edible oil and tied on wounds and boils.

Root and leaf paste is plastered over the

fractured area.

Leaf decoction with black pepper is taken orally

Grounded seeds are taken orally with hot 
13.

Nasturitium officinale R.Br.

(Brassicaceae)

Nelumbo nucifera Gaertn

(Nymphaeceae)

16.

Neptunia prostrata (Lamarck) Baillon (Mimosaceae)

Nymphaea nouchalli Burm.f.

(Nymphaeceae)

Nymphaea stellata Burm.f.

18. (Nymphaeceae)

19. Nymphoides indica (L.) Kuntze

(Gentianaceae)

Monochoria vaginalis Presl

20. (Pontederiaceae)

21. Plantago major L. (Plantaginaceae)

22. Sagittaria guyanensis Kunth

(Alismatacceae)
Sporocarp

Whole plant

Fruit

Leaves

Tender shoots

Whole plant

Root

Roots

Whole plant

Leaves

Whole plant

Whole

Leaves

Seeds, roots

Root

Whole plant
Throat inflammation

Improve eyesight

Check vomitting

Dysuria

White discharge

Jaundice

Dysentery

Check conception

Inducing puberty

Toothache

Jaundice

Dysentery

Nausea

Cuts, wounds

Stomachic

Piles

Fever
Sporocarps are crushed and applied on throat with the help of finger to cure throat inflammation in children

Whole plant is used as vegetable to improve eyesight

One fruit is crushed and given with $20 \mathrm{ml}$ of water three times a day for check vomiting in children

Half glass of leaf decoction is taken orally about a fortnight

The decoction of the young twigs are taken with common salt

The whole plant is a very good tonic particularly for those who are suffering from jaundice

Root extract is taken with curd

$10 \mathrm{~g}$ roots and $3 \mathrm{~g}$ of seed of Crotalaria juncea are ground into paste and taken with water on the date of menstruation

Paste of whole plant in water is applied around the navel

Leaves given fresh

Decoction of the plant is drunken three

teaspoonfuls every morning.

Root power is used in dysentery

Decoction of fresh root given

Powdered leaves are applied to cuts and wounds. Decoction of seeds, roots, and leaves are taken to treat stomach disorder.

Root paste is applied to cure piles.

Plant juice is drunk to cure fever 


\section{RESULTS AND DISCUSSION}

During the field survey, ethno medicinal data of 22aquatic plant species under 19 genera belonging to 17 families have been documented. Among the ethno-medico-botanical values of the species, the family Nymphaeaceae was most frequently represented with a total of 3 species, followed by Pontederiaceae, Amaranthaceae and Convolvulaceae having 2 species. Whole plants part and leaves are predominantly used when compare to other parts of plants. The data on the medicinally important plants indicate that the observed species were used to treat 37 ailments including fever, gynaecological complaints, stomach disorders, jaundice, snake bite, skin diseases, rheumatism, ulcer, wounds, boils, cuts and wounds, diseases of blood, and other diseases. (Table 1).

Local communities and vaidhyas in District living with the day to day practices and there are no written documents. Moreover, the existing knowledge on traditional uses of plants are destroying in fast pace, because the lack of interest of local youth to learn the traditional knowledge from the old herbal healer. It is also felt that the valuable and time-tested knowledge on the medicinal uses of plants are also is appearing due to modernization, acculturation, forests destruction, urbanization, industrialization, etc. Scientific investigations through the evaluation of these aquatic plants for their biological activity and isolation of active constituents responsible for their medicinal properties which will give a lead to develop new natural drug molecules so as to reach he benefit of research for the welfare of human beings.

\section{REFERENCES}

Indirani, B. (2010). Studies of Ammonia, Nitrate and Phosphate content of Pazhayar River, Kanyakumari District, Tamil Nadu, India. J. Basic Appl. Biol. 4(3): 221-225.

Jain, S.K. (2004). Credibility of traditional knowledge. The criterion of multi-location and multiethnic use. Indian J. Tradit. Know. 3(1): 137.

Kirtikar, K.R. and B.D. Basu, (1980). Indian Medicinal Plants, (Bishen Singh Mahindra Pal Singh, Dehradun).

Lambert, J., J. Srivastava and N. Vietmeyer, (1997). Medicinal Plants: Rescuing a Global Heritage, (World Bank Technical Paper).

Lawrence, B. (2010). Eutrophication status of Tamiraparani River at Kuzhithuri. J. Econ. Taxon. Bot. 30(3): 105-109.

Maity, D., N. Pradhan and A.S. Chauhan, (2004). Folk uses of some medicinal plants from North Sikkim. Indian J. Tradit. Know. 3(1): 66.

Maya, S, Menon, S.V, and Nair, S.G 2003. Economic importance of river vegetation of Kerala - A case study. J. Econ. Taxon. Bot. 27 (4): 796-803.

Panda, A., and M.K. Misra, (2011). Ethnomedicinal survey of some wetland plants of South Orissa and their conservation. Indian J. Tradit. Know. 10(2): 296-303.

Regini Balasingh, G.S. (2011). Studies on phytoplankton diversity and seasonal abundance of a perennial pond in Kanyakumari -Tamil Nadu, India. J. Basic Appl. Biol. 4(3): 188193.

Swapna, M.M., R. Prakashkumar, K.P. Anoop, C.N. Manju and N.P.A. Rajith, (2011). Review on the medicinal and edible aspects of aquatic and wetland plants of India. J. Med. Plants Res. 5(33): 7163-7176.

Thangam, R.T., R. Meena and H. Prabhavathy, (2010). Studies of epiphytic algal flora of the selected $t$ emporary ponds of Agasteeswaram, Kanyakumari District. J. Basic Appl. Biol. 4(3): $194-198$.

Vedavathy, S. (2003). Scope and importance of traditional medicine. Indian J. Tradit. Know. 2(20): 236. 